\title{
Preparation and Analysis of Mechanical Properties of Short Sisal and Glass Fiber Reinforced Composite
}

\author{
Sandeep C. Dhaduti ${ }^{1}$, Shridhar H. B ${ }^{1}$, S. N. Mathad ${ }^{2}$
}

${ }^{1}$ Department of Mechanical Engineering, K. L. E. Institute of Technology, Hubballi-580030, Karnataka, India

${ }^{2}$ Department of Engineering Physics, K. L. E. Institute of Technology, Hubballi-580030, Karnataka, India

\begin{abstract}
The present work surveys the research work published in the field of sisal fiber reinforced polymer composites with special reference to the properties of sisal fiber, processing techniques, mechanical properties of the composites. Interest is warranted due to the advantages of these materials compared to others, such as synthetic fiber composites, including low environmental impact and low cost and support their potential across a wide range of application. The advantages of natural fiber over traditional reinforcing materials such as glass fiber, talc and mica are acceptable specific strength properties, low lost, low density, high toughness, good thermal properties and biodegradability. The combination of sisal fiber and glass fiber for reinforcing epoxy polymers gives enhanced mechanical properties. The work deals with the utilization of sisal fiber and glass fiber reinforcement in polymer. The objective of the work is to compute mechanical properties such as tensile and hardness of randomly oriented sisal fiber and glass fiber reinforced epoxy composites. In this work, sisal fiber \% weight is varied from 2 to 8 with constant $2 \%$ weight of glass fiber. From the work, it was found that ductility, modulus of elasticity and hardness gradually improved.
\end{abstract}

KEYWORDS: Sisal Fiber, Epoxy, Glass fiber, tensile properties, Hardness

https://doi.org/10.29294/IJASE.5.3.2019.1009-1016

(c) 2019 Mahendrapublications.com, All rights reserved

\section{INTRODUCTION}

In the recent past, the use of polymers has become most preferred materials for various manufacturing applications due to several attractive properties, including light weight, ease of processing and cost-effectiveness [1]. Hence, many significant research attempts are made to utilize polymers in different industrial applications, using various kinds of reinforcements including fibers that are reinforced into the polymers to increase their physical and mechanical properties of the composite as whole. Due to increased environmental awareness and having more environmental regulations, the growing demand for using nonconventional materials leads to the development of renewable, recyclable, biodegradable, and sustainable and eco-friendly materials [2-6].The interest in natural fiberreinforced polymer composite materials is rapidly growing both in terms of their industrial applications and in terms of fundamental research. These are renewable, cheap, completely or partially recyclable, and biodegradable. Their availability, renewability, low density, and price as well as satisfactory mechanical properties make them an attractive ecological alternative to glass, carbon and man-made fibers used for the manufacturing of composites. In addition, natural fibers reinforced polymers are considered as lightweight and low-cost in comparison with many synthetic composites [4-6].

Natural fibers are more comfortable to handle and which have beneficial thermal and acoustic insulation properties. Recently, a number of significant industries, such as the automotive, construction and packaging industries have been fascinated in the development of new green natural fiber reinforced composite materials [4-7]. All natural fibers are categorized in three categories, based on main sources: animals, vegetables and minerals, as shown in Fig. 1

Recent studies have investigated the development of biodegradable composite materials using natural fibers such as pineapple [8], flax [4], bamboo [9], oil palm empty fruit bunch [10.] silk [11], jute [12], kenaf [13], rice husk [14] ramie [15] and sisal[16-17], as a reinforcement for biodegradable plastics. The versatile advantages of natural fibers over man-made glass and carbon fibers are inexpensive, low density, comparable specific tensile properties, non-abrasive to the equipments, non-irritation to the skin, reduced energy consumption, less health risk, renewability, recyclability and bio-degradability [18].

Vegetable fibers are broadly comprised primarily of cellulose: examples include cotton, flax, jute, ramie, sisal, and hemp. In the manufacture of paper and cloth cellulose fibers are typically used. These fibers can be further categorized into the following:

i. Seed fiber: Fibers collected from seeds or seed cases. Eg. cotton and kapok

ii. Leaf fiber: Fibers collected from leaves. e.g. sisal and agave.

iii. Bast fiber (skin fiber): Fibers is extracted from the skin or bast surrounding the stem of their respective plant which prepossess higher tensile strength than other fibers. Hence used in durable yarn, fabric, packaging, and paper. Most common example are flax, jute, kenaf, industrial hemp, ramie, rattan, soybean fiber, and even vine fibers and banana fibers.

*Corresponding Authors: scdhaduti@yahoo.com/physicssiddu@gmail.com

Received: 05.01.2019 Accepted: 25.02.2019 Published on: 27.02.2019

Sandeep C. Dhaduti et al., 
iv. Fruit fiber: Fibers are collected from the fruit of the v. Stalk fiber: Fibers are actually the stalks of the plant. Eg. plant, e.g. coconut (coir) fiber.

Straws of wheat, rice, barley and other crops including bamboo and grass. Tree wood is also such a fiber.

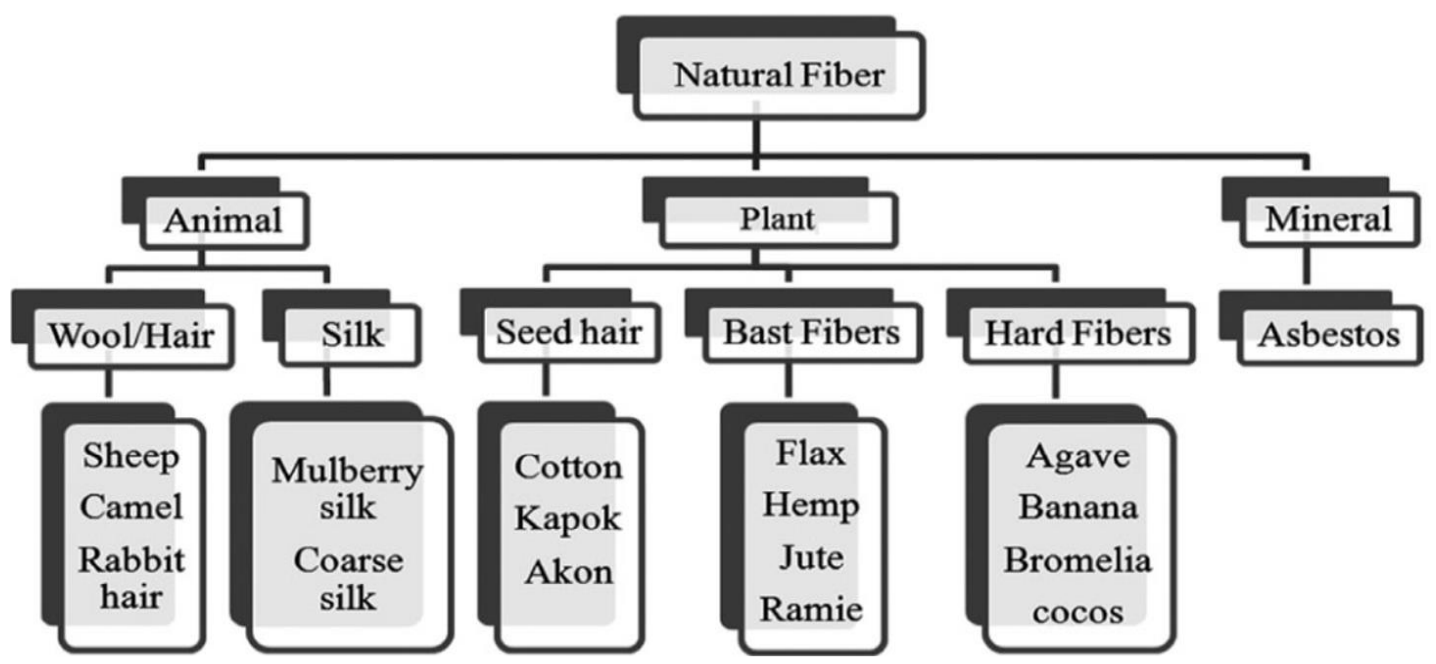

Figure 1 Source of Natural fiber [7]

Table 1: Properties of some natural fibres and the main type of glass fibre (E-glass) [19]

\begin{tabular}{|c|c|c|c|c|c|c|c|}
\hline Fibre & $\begin{array}{l}\text { Density } \\
\text { (g/cm3) }\end{array}$ & $\begin{array}{c}\text { Length } \\
\text { (mm) }\end{array}$ & $\begin{array}{c}\text { Failure } \\
\text { strain } \\
(\%)\end{array}$ & $\begin{array}{c}\text { Tensile } \\
\text { strength } \\
\text { (MPa) }\end{array}$ & $\begin{array}{c}\text { Stiffness/ } \\
\text { Young's } \\
\text { modulus } \\
\text { (GPa) }\end{array}$ & $\begin{array}{c}\text { Specific } \\
\text { tensile } \\
\text { strength } \\
\left(\mathrm{MPa} / \mathrm{g} \mathrm{cm}^{-3}\right)\end{array}$ & $\begin{array}{c}\text { Specific } \\
\text { Young's } \\
\text { modulus } \\
\left(\mathrm{GPa} / \mathrm{g} \mathrm{cm}^{-3}\right)\end{array}$ \\
\hline Ramie & 1.5 & $\begin{array}{l}900- \\
1200\end{array}$ & $2.0-3.8$ & $400-938$ & $44-128$ & $270-620$ & $29-85$ \\
\hline Flax & 1.5 & 5-900 & $1.2-3.2$ & $\begin{array}{l}345- \\
1830\end{array}$ & $27-80$ & $230-1220$ & $18-53$ \\
\hline Hemp & 1.5 & $5-55$ & 1.6 & $\begin{array}{l}550- \\
1110 \\
\end{array}$ & $58-70$ & $370-740$ & $39-47$ \\
\hline Jute & $1.3-1.5$ & $1.5-120$ & $1.5-1.8$ & $393-800$ & $10-55$ & $300-610$ & $7.1-39$ \\
\hline $\begin{array}{c}\text { Harakek } \\
\text { e } \\
\end{array}$ & 1.3 & $4-5$ & $4.2-5.8$ & $440-990$ & $14-33$ & $338-761$ & $11-25$ \\
\hline Sisal & $1.3-1.5$ & 900 & $2.0-2.5$ & $507-855$ & $9.4-28$ & $362-610$ & $6.7-20$ \\
\hline Alfa & 1.4 & 350 & $1.5-2.4$ & $188-308$ & $18-25$ & $134-220$ & $13-18$ \\
\hline Cotton & $1.5-1.6$ & $10-60$ & $3.0-10$ & $287-800$ & $5.5-13$ & $190-530$ & $3.7-8.4$ \\
\hline Coir & 1.2 & $20-150$ & $15-30$ & $131-220$ & $4-6$ & $110-180$ & $3.3-5$ \\
\hline Silk & 1.3 & $\begin{array}{c}\text { Continu } \\
\text { ous }\end{array}$ & $15-60$ & $\begin{array}{l}100- \\
1500\end{array}$ & $5-25$ & $100-1500$ & $4-20$ \\
\hline Feather & 0.9 & $10-30$ & 6.9 & $100-203$ & $3-10$ & $112-226$ & $3.3-11$ \\
\hline Wool & 1.3 & $38-152$ & $13.2-35$ & $50-315$ & $2.3-5$ & $38-242$ & $1.8-3.8$ \\
\hline E-glass & 2.5 & $\begin{array}{c}\text { Continu } \\
\text { ous }\end{array}$ & 2.5 & $\begin{array}{c}2000- \\
3000\end{array}$ & 70 & $800-1400$ & 29 \\
\hline
\end{tabular}

Sandeep C. Dhaduti et al., 
The most used natural fibers are cotton, flax and hemp, although sisal, jute, kenaf, and coconut are also widely used. Hemp fibers are mainly used for ropes and aerofoils because of their high suppleness and resistance within an aggressive environment. Hemp fibers are, currently used as a seal within the heating and sanitary industries.

Animal fibers generally comprise proteins; examples include silk, wool, angora, mohair and alpaca.

i. Animal hair (wool or hairs): Fiber or wool taken from animals or hairy mammals. Eg. sheep's wool, goat hair (cashmere, mohair), alpaca hair, horse hair etc.

ii. Silk fiber: Fiber collected from dried saliva of bugs or insects during the preparation of cocoons. Examples include silk from silk worms.

Avian fiber: Fibers from birds, e.g. feathers and feather fiber

Although mineral-based natural fibres exist within the asbestos group of minerals and used extensively in composites, and are avoided due to associated health issues (carcinogenic through inhalation/ingestion) and are banned in many countries. [19].

The drawbacks such as incompatibility with the hydrophobic polymer matrix, the inclination to form aggregates during processing, and also poor resistance to moisture greatly reduce the potential of natural fibers to be employed as reinforcement in polymers [1-4]. Table 01 shows properties of some natural fibers and the main type of glass fiber (E-glass). It can be seen that, flax, hemp and ramie fiber are amongst the cellulose-based natural fibers having the highest specific Young's moduli and tensile strengths [19].

Generally, higher performance is achieved with fibers having higher cellulose content and with cellulose microfibrils aligned more in the fiber direction, which tends to occur in bast fibers (Eg. flax, hemp, kenaf, jute and ramie) that have higher structural requirements in providing support for the stalk of the plant [19]

Due to the immense scope for development of natural fiber reinforced polymer composites and to find, an alternative to the glass fiber reinforced composites is imminent due to its non-biodegrading property. So, development of a high performance composite using natural fibers has been a major area of concern. The natural fiber reinforced composites was synthesized by using sisal and glass fiber reinforced with epoxy resins. The main objective of the present work is to fabricate of a new class of epoxy-based composites reinforced with randomly oriented short sisal fibers. Prepare specimens by varying the percentage weight of glass fiber and sisal fiber. Investigate mechanical properties such as tensile strength, flexural strength and hardness. Study the influence of percentage of glass fiber on mechanical properties of the composites.

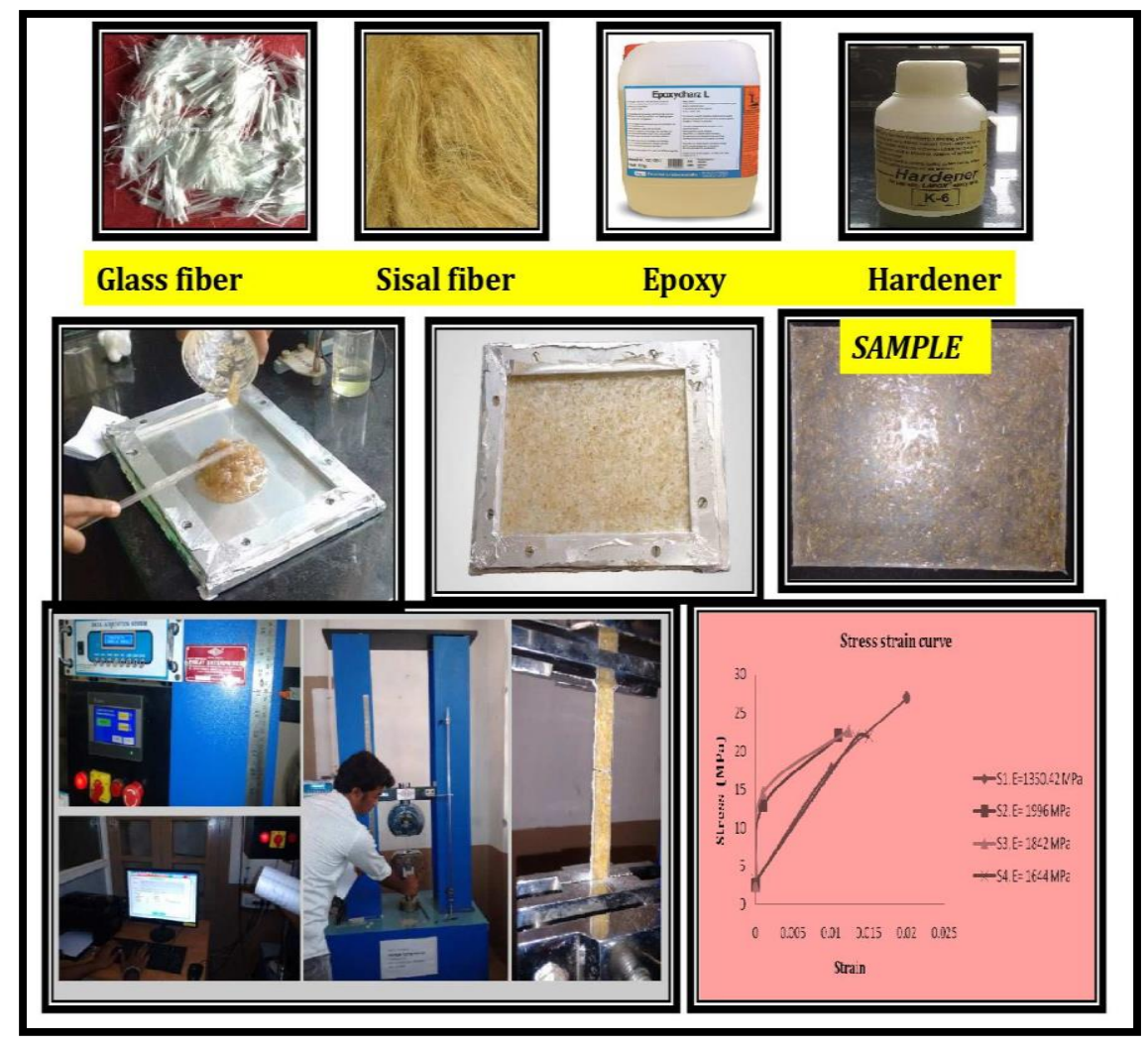

Figure 2 Schematic work-flow of proposed work.

Sandeep C. Dhaduti et al., 


\section{EXPERIMENATAL METHODS AND MATERIALS}

2.1 Fiber Material

Sisal fibre is extracted from the leaves of the plant Agave sisalana, which was originated from Mexico and is now mainly cultivated in East Africa, Brazil, Haiti, India and Indonesia $[16,17,20]$. Sisal fiber is one of the most widely used natural fibers and is very easily cultivated. Sisal is a perennial plant identified by its 50 - 150 thick, spiky, long and rigid spirally arranged leaves. Upon maturation, pale yellow/shiny white fiber can be extracted from leaves by retting followed by washing and drying.

A sisal plant produces about $200 \pm 250$ leaves and each leaf contains $1000 \pm 1200$ fiber bundles, which is composed of $4 \%$ fiber, $0.75 \%$ cuticle, $8 \%$ dry matter and $87.25 \%$ water [1]. Therefore, normally a leaf weighing about $600 \mathrm{~g}$ will yield about $3 \%$ by weight of fiber with each leaf containing about 1000 fiber [21]. Fig. 2 shows sisal plants and fibers after extraction. Sisal fiber contains $78 \%$ cellulose, $8 \%$ lignin, $10 \%$ hemi-celluloses, $2 \%$ waxes and about $1 \%$ ash by weight. These large variations in chemical compositions of sisal fiber are a result of its different source, age, measurement methods, etc. The length of sisal fiber is between 1.0 and $1.5 \mathrm{~m}$ and the diameter is about $100 \pm 300 \mathrm{~mm}[16,17,21]$.

\subsection{Matrix}

Commercially available Polymer Lapox L12 epoxy resin and K-6 hardener supplied by "KATWA SOFTWARE TECHNOLOGIES" used is this work. The Lapox L12 epoxy resin had density of $1.15 \mathrm{gm} / \mathrm{cm}^{3}$, viscosity of 9000-12000 $\mathrm{mPa}$.s at $25{ }^{\circ} \mathrm{C}$. The hardener used was K-6 having density of $0.954 \mathrm{gm} / \mathrm{cm}^{3}$.

\subsection{Extraction of Fiber and Mould Preparation}

The processed sisal fibers and glass fibers were taken from local manufacturing suppliers. And these fibers are chopped to average length of $2-3 \mathrm{~mm}$ in the laboratory using scissors. Aluminum was used for preparation of tensile test specimen mold. The size of mould for tensile test specimen was $230 * 160 * 3 \mathrm{~mm}$. The size of mould used for preparation of hardness test specimen mold was $120 * 80 * 6 \mathrm{~mm}$. Based on the size of the mould for both tests, the amount of weight of fiber matrix quantity was calculated. The specimens were prepared with varying percentage composition of sisal with fixed percentage composition of glass fiber.

The composition of test specimens for tensile and hardness are as shown in Table 2 and Table 3
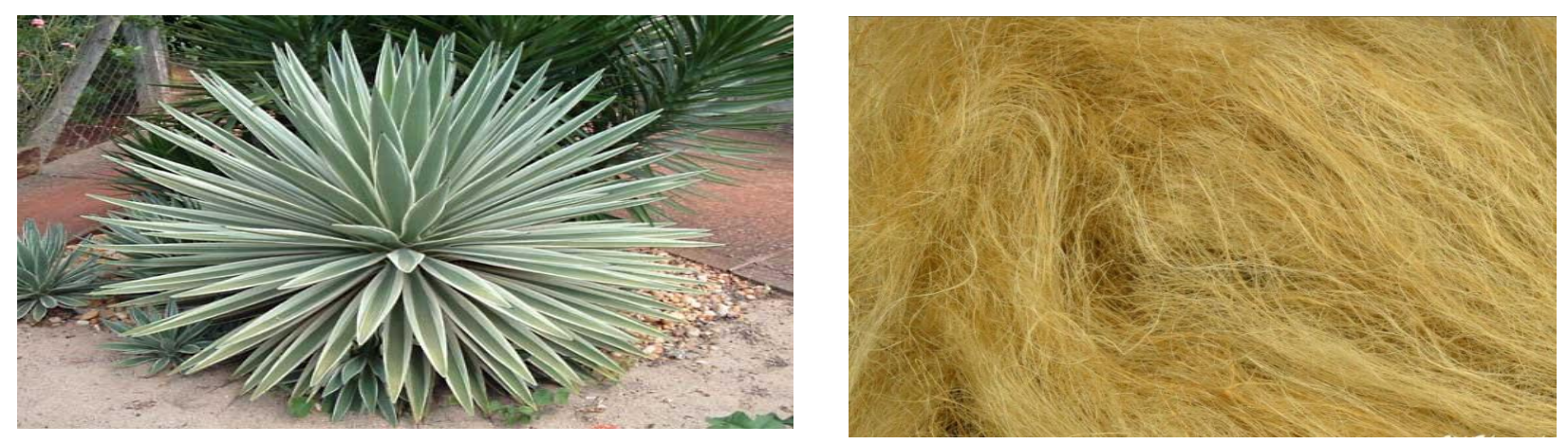

Figure 3 Sisal plants and fibers after extraction.

Table 2: Composition table for tensile test specimens

\begin{tabular}{|c|c|c|c|c|c|c|}
\hline \multirow{2}{*}{ Sample ID } & \multicolumn{2}{|c|}{ Epoxy } & \multicolumn{2}{c|}{ Sisal fiber } & \multicolumn{2}{c|}{ Glass fiber } \\
\cline { 2 - 7 } & \%wt & $\begin{array}{c}\text { Wt in } \\
\text { gm }\end{array}$ & \%wt & $\begin{array}{c}\text { Wt in } \\
\text { gm }\end{array}$ & \%wt & $\begin{array}{c}\text { Wt in } \\
\text { gm }\end{array}$ \\
\hline S1 & 96 & 137.28 & 2 & 2.34 & 2 & 2.34 \\
\hline S2 & 94 & 134.42 & 4 & 4.68 & 2 & 2.34 \\
\hline S3 & 92 & 131.56 & 6 & 7.02 & 2 & 2.34 \\
\hline S4 & 90 & 128.70 & 8 & 9.36 & 2 & 2.34 \\
\hline
\end{tabular}

Table 3: Composition table for Hardness test specimens

\begin{tabular}{|c|c|c|c|c|c|c|}
\hline \multirow{2}{*}{ Sample ID } & \multicolumn{2}{|c|}{ Epoxy } & \multicolumn{2}{c|}{ Sisal fiber } & \multicolumn{2}{c|}{ Glass fiber } \\
\cline { 2 - 7 } & \%wt & $\begin{array}{c}\text { Wt in } \\
\text { gm }\end{array}$ & \%wt & $\begin{array}{c}\text { Wt in } \\
\text { gm }\end{array}$ & \%wt & Wt in gm \\
\hline S1 & 96 & 73.92 & 2 & 1.26 & 2 & 1.26 \\
\hline S2 & 94 & 72.38 & 4 & 2.52 & 2 & 1.26 \\
\hline S3 & 92 & 70.84 & 6 & 3.78 & 2 & 1.26 \\
\hline S4 & 90 & 69.30 & 8 & 5.04 & 2 & 1.26 \\
\hline
\end{tabular}

Sandeep C. Dhaduti et al., 


\subsection{Composite Preparation}

i. Weighing the calculated amount of Glass fiber and sisal fiber as above calculated proportion in digital weighing machine as shown in Fig. 4. The least count of digital weighing machine is $0.0001 \mathrm{gms}$.

ii. Cutting the long length glass fiber into $3 \mathrm{~mm}$ short length fibers for random orientation of glass fiber as shown in Fig. 5

iii. Mixing the chopped glass fiber with calculated amount of epoxy (weighed) and the mixture is stirred for uniform mixing then heated up to certain duration in bath sonicator as shown in Fig. 6 and 7. To reduce viscosity of epoxy that will help in uniform distribution of mixture when it is pouring. iv. Calculated amount of sisal (weighed) is mixed with heated mixture (glass fiber + epoxy) and stirred for uniform mixing then mixture is again heated for certain duration as shown in Fig. 8

v. After heating of mixture (sisal + glass fiber + epoxy) is added as shown in Fig. 9, by calculated amount of hardener, properly stirred.

vi. Then pouring composition mixture in to the aluminum mold as shown in Fig. 10, and allowed it for solidifying process as shown in Fig. 11. Before pouring, foil the mold with aluminum foil.

vii. After solidifying, the mold is de-molded and specimen plates were taken out and as shown in Fig. 12. This procedure repeated for all the type of composition.
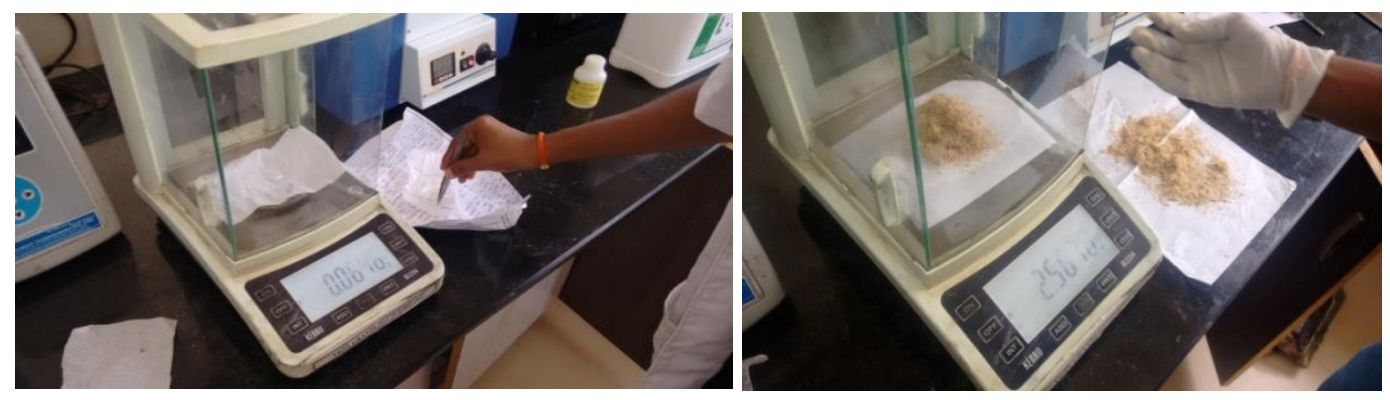

Figure 4 Weighing of Glass fiber and Sisal fiber

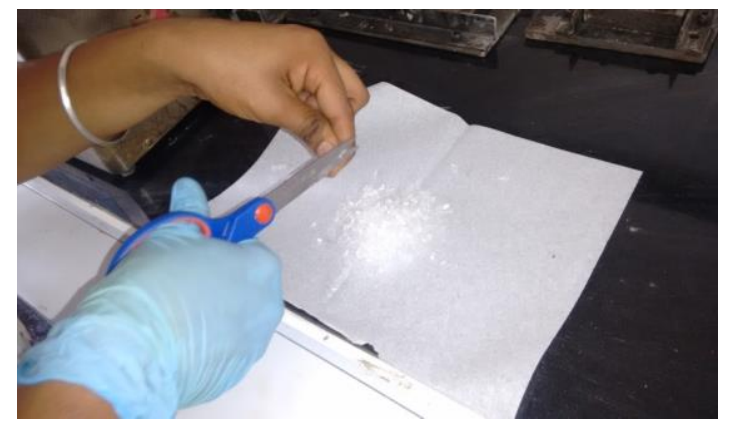

Figure 5 Cutting Glass fiber to $3 \mathrm{~mm}$ short length fiber

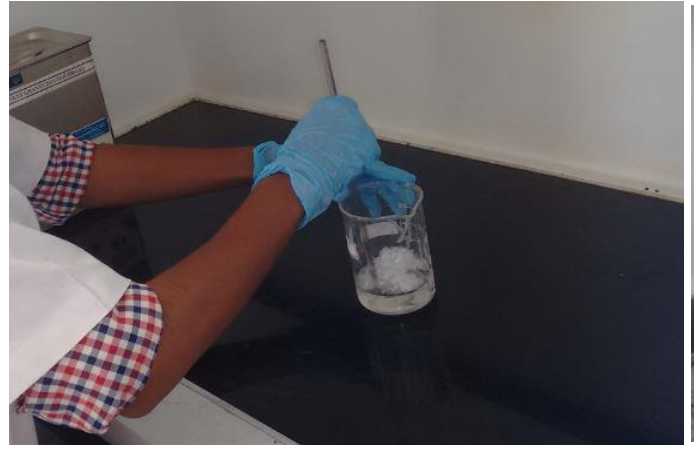

Figure 6 Mixing of Glass fiber

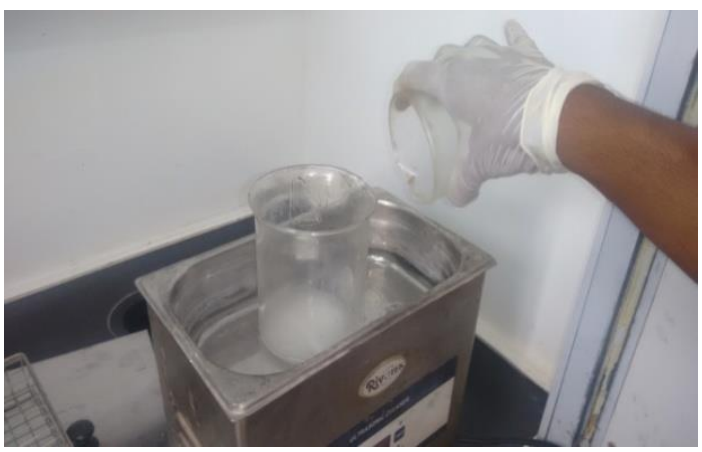

Figure 7 Mixture heating in bath sonicator

Sandeep C. Dhaduti et al., 


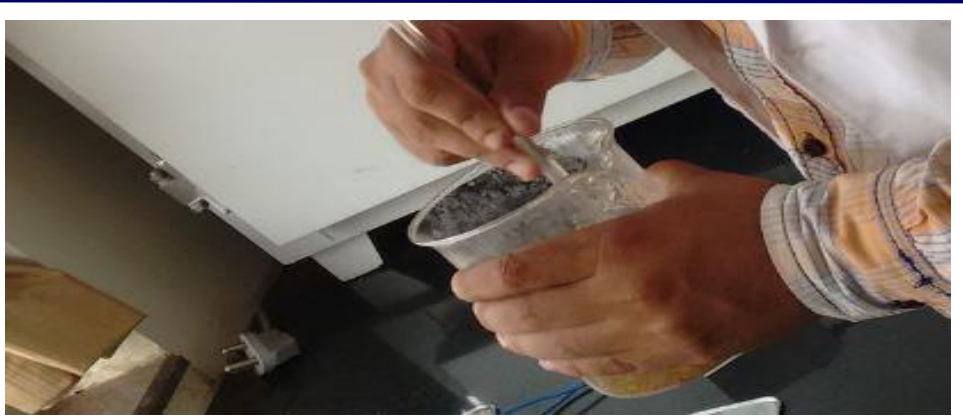

Figure 8 Mixing the sisal to the mixture

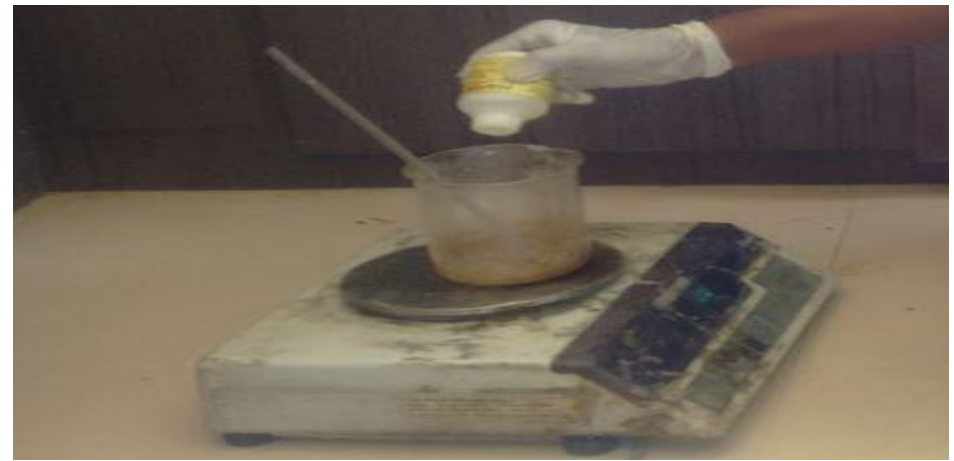

Figure 9 Adding hardener to mixture

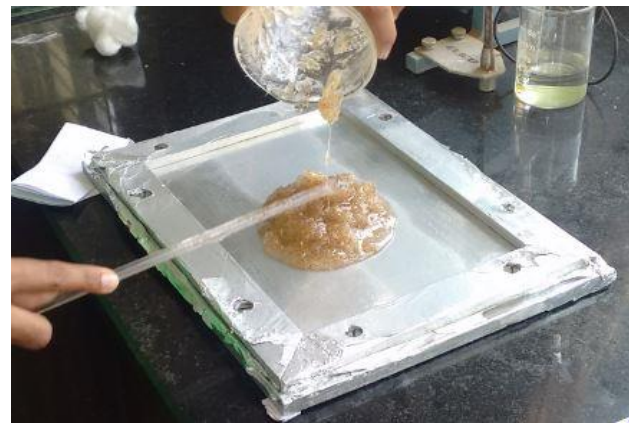

Figure 10 Pouring

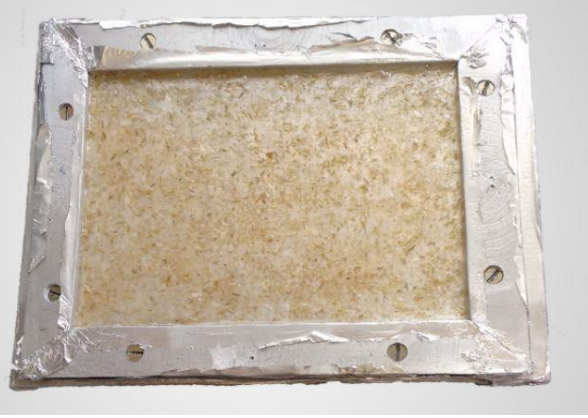

Figure 11 After pouring

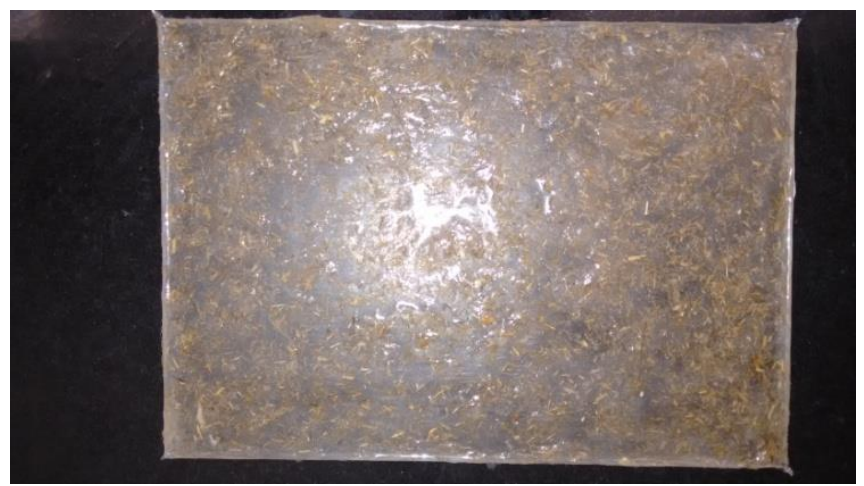

Figure 12 Specimen after de-molding

After demoulding, the standard test specimens were cut according to ASTM Std. ASTM Std. D3039 for tensile test specimen and D785 for hardness. The composite specimens were casted as per the ASTM D D3039 to measure the tensile properties. The guage length, width and thickness of the specimens were 100, 13 and $3 \mathrm{~mm}$, respectively. The hardness properties of the composites were studied by applying indentation load normal to surface of the test specimen. Three specimens of varying fiber composition were tested to investigate tensile strength and hardness.

\section{Sandeep C. Dhaduti et al.,}




\section{RESULTS AND DISCUSSION}

\subsection{Tensile Properties}

The prepared composite specimens S1, S2, S3 and S4 as discussed in Table 02 are subjected for tensile loading. The values of load and displacement for corresponding samples were obtained from the post processer of UTM machine. The values of load were noted down to calculate stress values. Similarly in order to get the corresponding strain values, displacement with respect to gauge length were also recorded.

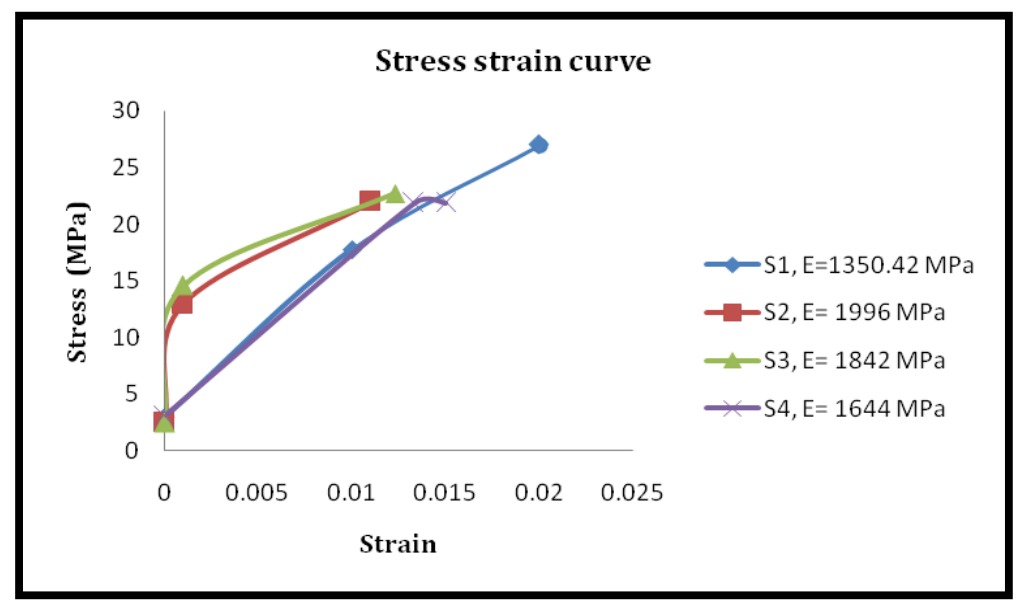

Figure 13 Stress Against Strain for Various Test Specimens

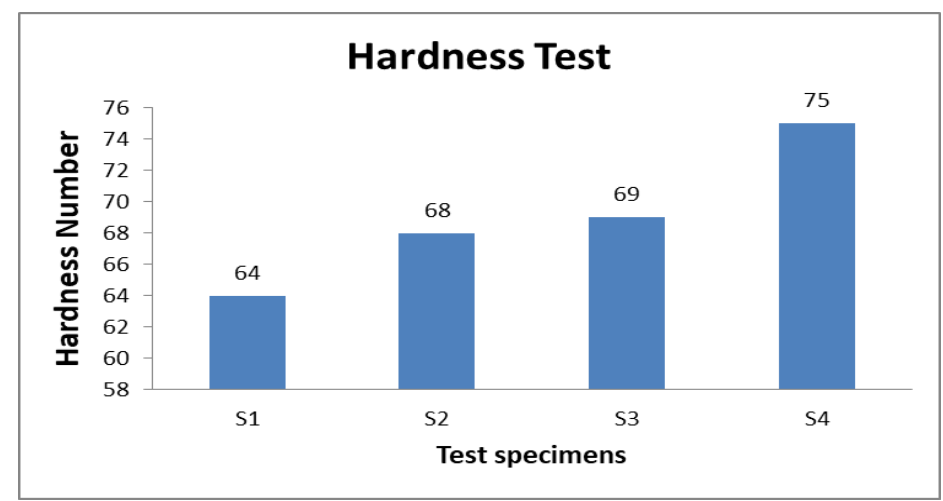

Figure 14 Variation of hardness for different test samples

The Fig. 13 shows that the stress increases linearly with respect to strain for all composites. The tensile modulus of S2 specimen having 4\% sisal, 2\% glass fiber, 94\% epoxy was found to maximum when compared to other test specimens. With increase in compostion of sisal fiber, tensile modulus decreased.

\subsection{Hardness}

The hardness of the composite samples was determined by using Rockwell hardness testing machine. For each of the specimen, surface hardness was obtained. The results were tabulated and variations of the hardness against various specimens are shown in Fig. 14.

\section{CONCULSION}

With the aim of development and study on mechanical properties of sisal and glass fiber based composites have been studied in this work. The ductility was observed to be more in case of S2 (composition 8\% sisal and 92\% epoxy) sample. Young's modulus was more in case of S3 (composition 6\% sisal and 94\% epoxy) sample. Now on addition of $2 \%$ wt of glass fiber to the sisal fiber reinforced composite ductility was more in case of S1 (composition 2\% sisal, 2\% glass fiber and 96\% epoxy) sample and Young's modulus was more in case of S2 (composition $4 \%$ sisal, 2\% glass fiber and 94\% epoxy) sample. Hardness was observed to be more in case of S4 ( $8 \%$ sisal, $2 \%$ glass fiber and 90\% epoxy) sample, increase in fiber content (fiber load) enhances the hardness value of sisal and glass fiber reinforced epoxy composite. The results obtained from this work shows better mechanical properties for the casted composite samples.

\section{REFERENCES}

[1] Chandramohan, D. and Marimuthu, K. (2011) A Review on Natural Fibers. IJRRAS, 8, 194-206 2.

\section{Sandeep C. Dhaduti et al.,}


[2] Ashik,KP., Ramesh S. Sharma, A Review on Mechanical Properties of Natural Fiber Reinforced Hybrid Polymer Composites, Journal of Minerals and Materials Characterization and Engineering, 2015, 3, 420-426.

[3] Oksman K, Selin JF. Plastics and composites from polylactic acid. In: Wallenberger FT, Weston N, editors. Natural fibers, plastics and composites. Boston: Kluwer Academic Publishers; 2004. p. 14965. chapter 10 .

[4] Sahari,J., and S.M. Sapuan, "Natural-fibre reinforced biodegradable polymer composites", Rev. Adv. Mater. Sci. 30 (2011) 166-174

[5] Masud S. Huda, Lawrence T. Drzal , Amar K. Mohanty , Manjusri Misra, Effect of fiber surface-treatments on the properties of laminate biocomposites from poly(lactic acid) (PLA) and kenaf fibers, Composites Science and Technology 68 (2008) 424-432.

[6] Mohanty AK, Misra M, Drzal LT. Sustainable biocomposites from renewable resources: opportunities and challenges in the green materials world. J Polym Environ 2002;10(1/2):19-26.

[7] Emad Omrani, Pradeep L. Menezes, Pradeep K. Rohatgi, State of the art on tribological behavior of polymer matrix composites reinforced with natural fibers in the green materials world, Engineering Science and Technology, an International Journal 19 (2016) 717-736

[8] Liu, W., Misra, M., Askeland, P., Drzal, L., Mohanty, A.K., 2005. 'Green' composites from soy based plastic and pineapple leaf fiber: fabrication and properties evaluation. Polymer 46, 710-2721

[9] Lee, S., Wang, S., 2005. Biodegradable polymers/bamboo fiber biocomposite with bio-based coupling agent. Composites Part A: Applied Science and Manufacturing 37, 80-91

[10] Rozman H.D, Tay G.S. "The effects of NCO/OH ratio on propylene oxide-modified oil palm empty fruit bunchbased polyurethane composites", J Appl Polym Sci 2008;110:3647-54
[11] Lee, S.M., Cho, D., Park, W.H., Lee, S.G., Han, S.O., Drzal,L.T., 2005. Novel silk/poly (butylene succinate) biocomposites: the effect of short fibre content on their mechanical and thermal properties. Composites Science and Technology 65,647-657.

[12] Plackett, D., Andersen, T.L., Pedersen, W.B., Nielsen, L., 2003.Biodegradable composites based on polylactide and jute fibres. Composites Science and Technology 63, 1287-1296

[13] Nishino, T., Hirao, K., Kotera, M., Nakamae, K., Inagaki, H.,2003. Kenaf reinforced biodegradable composite. Composites Science and Technology 63, 1281-1286

[14] Rozman H.D, Yeo Y.S, Tay G.S, Abubakar A. The mechanical and physical properties of polyurethane composites based on rice husk and polyethylene glycol. Polym Test 2003;22:617-23

[15] Lodha, P., Netravali, A.N., 2005. Characterization of stearic acid modified soy protein isolate resin and ramie fiber-reinforced "green" composites. Composites Science and Technology 65,1211-1225

[16] M.G. Prasad. A.G.Girimath, S. Rao, A.J.Vinekar, D.C.Patil, S.N.Timmanagoudar, S.N.Mathad, "FFT studies of Sisal fiber reinforced polymer composites", Int. J. Adv. Sci. Eng. Vol.4 No.2 605-611 (2017) 605

[17] Prasad.MG., A.G.Girimath, S. Rao, A.J.Vinekar, D.C.Patil, S.N.Timmanagoudar, S.N.Mathad, "FFT studies of Sisal fiber reinforced polymer composites", Int. J. Adv. Sci. Eng. Vol.4 No.2 605-611 (2017) 605

[18] Ku, K., H. Wang, N. Pattarachaiyakoop, M. Trada, A review on the tensile properties of natural fiber reinforced polymer composites, Composites: Part B 42 (2011) 856-873

[19] Pickering,KL., M.G. Aruan Efendy, T.M. Le, A review of recent developments in natural fibre composites and their mechanical performance, Composites: Part A 83 (2016) 98-112.

[20] Kuruvilla Joseph, et. al., A review on sisal fiber reinforced polymer composites, R. Bras. Eng. Agríc. Ambiental, Campina Grande, 3(3)367-379, 1999

[21] Yan Li, Yiu-Wing Mai , Lin Ye, Sisal fibre and its composites: a review of recent developments, Composites Science and Technology 60 (2000) 20372055. 